$\mathrm{DE}$

M E D I C I N A

T R O P I C A L

$\mathrm{DE}$

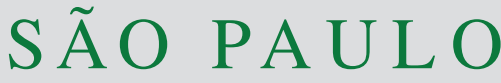

JOURNAL OF THE SÃO PAULO INSTITUTE OF TROPICAL MEDICINE

1 Universidad Nacional Autónoma de México, Facultad de Medicina, Centro de Medicina Tropical, Unidad de Investigación en Medicina Experimental, Ciudad de México, México

${ }^{2}$ Instituto Nacional de Medicina Genómica, Computational Genomics Laboratory, Ciudad de México, México

${ }^{3}$ Hospital General de México, Servicio de Infectología, Ciudad de México, México

Correspondence to: Ingeborg Becker Universidad Nacional Autónoma de México, Facultad de Medicina, Centro de Medicina Tropical, Unidad de Investigación en Medicina Experimental, Dr. Balmis 148, Col. Doctores, 06726, Ciudad de México, México Tel: +52 55 5623-2674

E-mail: becker@unam.mx

Received: 13 September 2018

Accepted: 8 November 2018

\section{Murine typhus in Mexico City: report of an imported case}

\author{
Sokani Sánchez-Montes', Pablo Colunga-Salas', Edith A. Fernández- \\ Figueroa ${ }^{1,2}$, María Luisa Hernández Medel $^{3}$, César Rivera Benítez ${ }^{3}$ Ingeborg \\ Becker $^{1}$
}

\section{ABSTRACT}

Murine typhus is endemic in several countries. We herein report an imported case of murine typhus caused by Rickettsia typhi in Mexico City. This is the first report of a case after almost 20 years since the last report. The species was confirmed by DNA sequencing and phylogenetic reconstruction.

KEYWORDS: Rickettsiosis. Mexico. Rickettsia typhi. PCR.

\section{INTRODUCTION}

Murine typhus, a neglected reemerging flea-borne rickettsiosis caused by Rickettsia typhi, is endemic around the world. It is transmitted mainly by infected feces of the oriental rat flea Xenopsylla cheopys and the cat flea Ctenocephalides felis $^{1-5}$. Murine typhus is considered a mild disease characterized by fever, maculopapular or petechial rash, body aches, muscle pain and chills ${ }^{6}$. However, in less than $3 \%$ of the cases, it can lead to a severe illness with kidney, liver, cardiac or pulmonary disease ${ }^{7,8}$. Murine typhus in endemic in Mexico (Yucatan), the US (Texas and Southern California) and Colombia (Caldas) ${ }^{9-11}$. In Mexico, human cases have been detected mainly in the Southern state of Yucatan, however two cases have been reported in the centre of the country (State of Mexico and Mexico city $)^{12-17}$. Using molecular techniques, we now report a new case of murine typhus in Mexico city after almost 20 years of the last published report.

\section{CASE REPORT}

On April 6, 2018 a 47-year-old female resident of Mexico city was referred to the Infectious Diseases Ward of Mexico General Hospital "Dr. Eduardo Liceaga" with sudden fever of unknown origin and a macular rash on the thorax and abdominal region (Figure 1). On presentation, the physical examination showed no abnormalities, vital signs were normal with no systemic symptoms, such as fever. During the interview, she referred having made several trips during the last four weeks, one to the South-Eastern State of Veracruz (on March 5, 2018) and another to the Northern State of Chihuahua (from March 20 to 23, 2018). She did not report activities in the wilderness or contact with animals.

On March 24, she presented a hyperaemic, painful, pruritic lesion on the left elbow measuring approximately $4 \times 4 \mathrm{~cm}$, with a well-defined border and a more hyperaemic central point, which was compatible with an arthropod sting, although the patient could not remember having been bitten. This was followed 

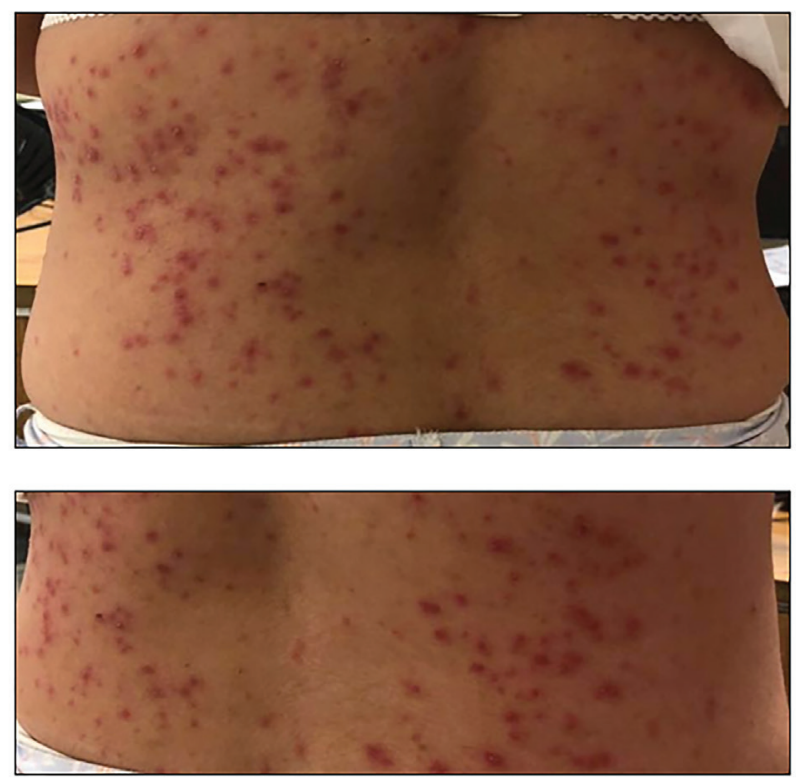

Figure 1 - Petechial rash on the thorax of the patient.

by persistent nocturnal headache, myalgias, arthralgias, diarrhea, hypersomnia, fever and generalized fatigue. After two days, maculopapular lesions appeared on arms, thighs, buttocks, back, thorax and abdominal region. Blood count showed leukocytosis of $12,400 / \mathrm{mm}^{3}$, neutrophilia $(71.1 \%)$ and haemoglobin $17.3 \mathrm{~g} / \mathrm{dL}$. Blood chemistry exhibited normal parameters.

A possible rickettsiosis was suspected and $5 \mathrm{~mL}$ of blood were taken in a vacutainer tube containing EDTA. The patient was immediately treated with $100 \mathrm{mg}$ of doxycycline taken orally, twice a day for 10 days. For the PCR analysis, $200 \mu \mathrm{L}$ of blood was centrifuged at $8,000 \mathrm{x} \mathrm{g}$ for $20 \mathrm{~min}$ and the supernatant was decanted. DNA was extracted from the pellet following the protocol for genomic DNA extraction by columns (DNEasy Blood and Tissue Kit,QIAGEN Inc., Germany). The DNA was quantified using a spectrophotometer (Nanodrop-1000, Thermo Fisher, USA) and adjusted to a concentration of $300 \mathrm{ng}$. In order to detect Rickettsia DNA, we amplified a fragment of $800 \mathrm{bp}$ of the outer membrane protein (ompB) by conventional PCR (cPCR), using the primers 120-N59 and 120-807 and conditions described by Roux and Raoult $^{18}$. The reaction mixture consisted of $12.5 \mu \mathrm{L}$ of PCR Go-Taq solution (Promega), $2 \mu \mathrm{M}$ of each primer, $6.5 \mu \mathrm{L}$ of nuclease-free water and $300 \mathrm{ng}$ of DNA in a final volume of $25 \mu \mathrm{L}$. Positive and negative controls were included (Rickettsia parkeri from Dermacentor parumapertus and nuclease free water, respectively). PCR products were analysed in $2 \%$ agarose gels. The positive PCR product was sequenced at Laboratorio de Biología Molecular y de la Salud, Universidad Nacional Autónoma de México. The sequence recovered in this study was deposited in GenBank with the following accession $\mathrm{N}^{\circ} \mathrm{MH} 717108$, and compared with those available in GenBank using the tool BLASTn. Sequences of the same species were downloaded for phylogenetic reconstruction analysis using the Maximum Likelihood method with 10,000 bootstrap in MEGA 6.0. We recovered a 800 bp sequence, which exhibited a similarity of $99.87 \%$ (799/800) with sequences of $R$. typhi previously detected in rats and human cases from Southern Mexico (KF241858.1) and US (AE017197.1), respectively. The phylogenetic analysis revealed a monophyletic cluster which encompasses our sequence and all of those deposited in GenBank with the name $R$. typhi, showing a support value of 100 (Figure 2).

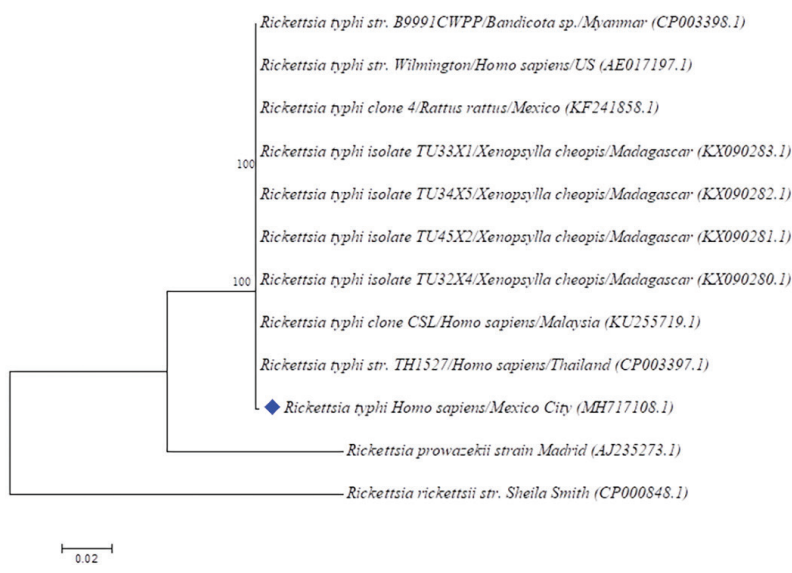

Figure 2 - Phylogenetic reconstruction of a fragment of the outer membrane protein (ompB) of Rickettsia typhi sequences deposited in Genbank using the GTR substitution model. The sequence recovered in this study is marked with a blue diamond.

After the third day of antibiotic use, the patient showed remission of symptomatology and the case was resolved after ten days of doxycycline treatment.

\section{DISCUSSION}

Murine typhus is an emerging disease, systematically studied in Southern Mexico, where it has been identified as the main rickettsial agent affecting the human population ${ }^{11-15}$. In these communities, it exhibits a complex life cycle, which includes several synanthropic vertebrate hosts such as the black rat and domestic animals such as $\operatorname{dog} \mathrm{s}^{19,20}$. Historic records show that a few cases of murine typhus had been reported in Mexico City and in the State of Mexico, all of which had been diagnosed by serological methods ${ }^{16,17}$. However, to the best of our knowledge, this is the first report of Rickettsia DNA in a human patient and the first to identify $R$. typhi as the etiological agent responsible for the disease in a patient in central Mexico. 
This Rickettsia species produces a mild febrile illness with low lethality, as compared to Rickettsia prowazekii, another member of the typhus group ${ }^{5,6}$. Even though considerable morbidity may occur, it is very likely that most cases resolve spontaneously and remain undetected ${ }^{13}$.

Even though the precise location of pathogen acquisition in our patient remains unknown due to her recurrent travels, we assumed she was infected during her visit to the State of Chihuahua based on the incubation period of the disease that ranges between 7-12 days. Furthermore, this State is endemic for murine typhus, where 13 cases have been reported between 2015 and $2017^{21}$.

Even though murine typhus had not been reported in Mexico City during the last 20 years ${ }^{17}$, our study now shows that it is important to suspect possible rickettsiosis when a patient exhibits fever accompanied by rash, since the disease may have been imported from other States after patients' travels. Furthermore, it is warranted to begin monitoring populations of rodents and associated fleas to establish the degree of human exposure to this bacterium.

\section{ACKNOWLEDGMENTS}

We thank Eva Gudiño Zayas for providing all the necessary facilities to report the case and Laura Márquez for processing sample for sequencing.

\section{FUNDING}

This research was supported by the grant PAPIIT IN211418.

\section{ETHICAL APPROVAL}

The current report was approved by the Ethics and Research Committee of the Medical Faculty of the UNAM (Universidad Nacional Autónoma de México), FMED/CI/ JMO/129/2017). The patient signed a written consent for the publication of the case.

\section{CONFLICT OF INTERESTS}

Authors declare to have no conflicts of interest.

\section{REFERENCES}

1. Chikeka I, Dumler JS. Neglected bacterial zoonoses. Clin Microbiol Infect. 2015;21:404-15.

2. Eisen RJ, Gage KL. Transmission of flea-borne zoonotic agents. Annu Rev Entomol. 2012;57:61-82.
3. Aung AK, Spelman DW, Murray RJ, Graves S. Rickettsial infections in Southeast Asia: implications for local populace and febrile returned travelers. Am J Trop Med Hyg. 2014;91:451-60.

4. Leulmi H, Socolovschi C, Laudisoit A, Houemenou G, Davoust B, Bitam I, et al. Detection of Rickettsia felis, Rickettsia typhi, Bartonella species and Yersinia pestis in fleas (Siphonaptera) from Africa. PLoS Negl Trop Dis. 2014;8:e3152.

5. Portillo A, Santibáñez S, García-Álvarez L, Palomar AM, Oteo JA. Rickettsioses in Europe. Microbes Infect. 2015;17:834-8.

6. Basra G, Berman MA, Blanton LS. Murine typhus: an important consideration for the nonspecific febrile illness. Case Rep Med. 2012;2012:134601.

7. van der Vaart TW, van Thiel PP, Juffermans NP, van Vugt M, Geerlings SE, Grobusch MP, et al. Severe murine typhus with pulmonary system involvement. Emerg Infect Dis. 2014;20:1375-7.

8. Stephens BE, Thi M, Alkhateb R, Agarwal A, Sharkey FE, Dayton $\mathrm{C}$, et al. Case report: fulminant murine typhus presenting with status epilepticus and multi-organ failure: an autopsy case and a review of the neurologic presentations of murine typhus. Am J Trop Med Hyg. 2018;99:306-9.

9. Hidalgo M, Salguero E, de la Ossa A, Sánchez R, Vesga JF, Orejuela L, et al. Murine typhus in Caldas, Colombia. Am J Trop Med Hyg. 2008;78:321-2.

10. Afzal Z, Kallumadanda S, Wang F, Hemmige V, Musher D. Acute febrile illness and complications due to murine typhus, Texas, USA. Emerg Infect Dis. 2017;23:1268-73.

11. Zavala-Velazquez JE, Yu XJ, Walker DH. Unrecognized spotted fever group rickettsiosis masquerading as dengue fever in Mexico. Am J Trop Med Hyg. 1996;55:157-9.

12. Zavala-Castro JE, Dzul-Rosado KR, Peniche-Lara G, Tello-Martín R, Zavala-Velázquez JE. Isolation of Rickettsia typhi from human, Mexico. Emerg Infect Dis. 2014;20:1411-2.

13. Zavala-Castro JE, Zavala-Velázquez JE, Sulú Uicab JE. Murine typhus in child, Yucatan, Mexico. Emerg Infect Dis. 2009;15:972-4.

14. Peniche Lara G, Dzul-Rosado KR, Zavala-Velázquez JE, ZavalaCastro J. Murine typhus: clinical and epidemiological aspects. Colomb Med (Cali). 2012;43:175-80.

15. Dzul-Rosado K, González-Martínez P, Peniche-Lara G, ZavalaVelázquez J, Zavala-Castro J. Murine typhus in humans, Yucatan, Mexico. Emerg Infect Dis. 2013;19:1021-2.

16. García-Acosta J, Aguilar-García CR. Tifus murino o endémico. Med Int Méx 2015;31:485-90.

17. Acuna-Soto R, Calderón-Romero L, Romero-López D, BravoLindoro A. Murine typhus in Mexico City. Trans R Soc Trop Med Hyg. 2000;94:45.

18. Roux V, Raoult D. Phylogenetic analysis of members of the genus Rickettsia using the gene encoding the outer membrane protein rOmpB (ompB). Int J Syst Evol Microbiol. 2000;50:1449-55. 
19. Peniche-Lara G, Dzul-Rosado K, Pérez-Osorio C, Zavala-Castro J. Rickettsia typhi in rodents and R. felis in fleas in Yucatán as a possible causal agent of undefined febrile cases. Rev Inst Med Trop Sao Paulo. 2015;57:129-32.

20. Martínez-Ortiz D, Torres-Castro M, Koyoc-Cardeña E, López K, Panti-May A, Rodríguez-Vivas I, et al. Molecular evidence of Rickettsia typhi infection in dogs from a rural community in Yucatán, México. Biomedica. 2016;36:45-50.
21. México. Secretaría de Salud. Dirección General de Epidemiología. Anuario de morbilidad 1984-2017. [cited 2018 Oct 8]. Available from: http://www.epidemiologia.salud.gob.mx/ anuario/html/anuarios.html 